\title{
Hubungan antara Status Gizi dengan Siklus Menstruasi pada Siswi MAN 1 Lamongan
}

\section{The Correlation between Nutritional Status and Menstrual Cycle of Female Students at Islamic Senior High School 1, Lamongan}

\author{
Nurul Maulid Dya *, Sri Adiningsih
}

\begin{abstract}
ABSTRAK
Latar Belakang : Pubertas merupakan masa yang terjadi pada usia remaja. Pubertas pada remaja putri ditandai dengan terjadinya menstruasi pertama kali (menarche). Remaja merupakan kelompok usia yang rentan mengalami gangguan menstruasi salah satunya yaitu siklus menstruasi yang tidak normal. Siklus menstruasi yang tidak normal dapat menjadi prediktor kesehatan reproduksi. Salah satu faktor yang menyebabkan siklus menstruasi yang tidak normal yaitu status gizi. Tujuan : Penelitian ini bertujuan untuk menganalisis hubungan antara status gizi dengan siklus menstruasi siswi MAN 1 Lamongan.

Metode : Penelitian dengan desain cross sectional ini dilakukan pada populasi siswi kelas X dan XI Madrasah Aliyah Negeri 1 Lamongan (MAN 1 Lamongan). Penentuan sampel dilakukan dengan simple random sampling dan didapatkan besar sampel sebesar 83 siswi. Data terkait siklus menstruasi didapatkan dengan wawancara menggunakan kuesioner. Data status gizi didapatkan dengan melakukan pengukuran tinggi badan, berat badan. Status gizi diklasifikasikan dengan menggunakan nilai tabel z-score IMT/U untuk anak perempuan usia 5-18 tahun dari Kemenkes RI. Analisis data menggunakan uji korelasi spearman dengan $\alpha=0,05$.

Hasil : Hasil penelitian menunjukkan bahwa responden dengan status gizi normal $(66,3 \%)$ sebagian besar memiliki siklus menstruasi yang normal $(62,7 \%)$. Responden dengan status giziobesitas cenderung mengalami siklus menstruasi yang tidak normal $(71,4 \%)$. Berdasarkan hasil uji statistik, diketahui bahwa terdapat hubungan antara status gizi dengan siklus menstruasi $(p=0,036)$

Kesimpulan :Terdapat hubungan antara status gizi dengan siklus menstruasi siswi MAN 1 Lamongan.
\end{abstract}

Kata kunci : Status Gizi, Siklus Menstruasi, Remaja

\section{ABSTRACT}

Background: Puberty is a period that occurs in adolescence. Puberty in young women is characterized by the occurrence of menarche. Adolescent is an age group that is prone to menstrual disorders, one of which is an abnormal menstrual cycle. Abnormal menstrual cycles can be predictors of reproductive health problems. One of the factors that causes an abnormal menstrual cycle is nutritional status.

Objective: This study aimed to analyze the relationship between nutritional status and menstrual cycles in female students of Islamic Senior High School Lamongan.

Method: This cross-sectional designed study was conducted on the 10th and 11th-grade students of Islamic Senior High School 1, Lamongan. The determination of the sample was done by simple random sampling to choose 83 students. Data related to the menstrual cycle was obtained by interview using a questionnaire. Nutrition status data was obtained by measuring height, weight. Nutritional status was classified by using the BMI/U z-score table values for girls aged 5-18 years from the Indonesian Ministry of Health. Data analyzed using the Spearman correlation test with $\alpha=0.05$.

Results: The results showed that respondents with normal nutritional status (66.3\%) mostly had normal menstrual cycles (62.7\%). Respondents with obesity tend to experience abnormal menstrual cycles (71.4\%). Based on the results of statistical tests, it was known that there was a relationship between nutritional status with the menstrual cycle $(p=0.036)$.

Conclusions: There was a relationship between nutritional statuses with the female students' menstrual cycle of Islamic Senior High School 1, Lamongan

Keywords:Nutritional Status, Menstrual Cycle, Adolescent 


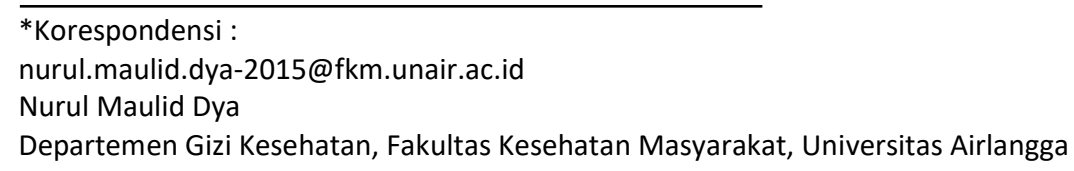

\section{PENDAHULUAN}

Salah satu fase dalam pekembangan manusia adalah masa remaja. Masa remaja merupakan suatu masa yang terjadi diantara masa anak-anak dan masa dewasa atau biasa disebut masa pubertas ${ }^{1}$. Menstruasi pertama kali atau menarchepada remaja perempuan merupakan salah satu tanda pubertas pada perempuan.Menstruasi merupakan suatu proses peluruhan dinding rahim dan disertai dengan pendarahan sebagai akibat tidak terjadinya proses pembuahan ${ }^{2}$. Menstruasi pertama kali terjadi karena kematangan sel telur dan produksi hormon esterogen ${ }^{3}$. Menstruasi menandakan mulainya masa reproduktif pada kehidupan seorang ditandai denganmenarche hingga terjadinya menopause. Remaja merupakan kelompok usia yang rentan mengalami gangguan menstruasi seperti disminorea, lama dan jumlah darah haid, siklus menstruasi yang tidak teratur, dan gangguan lainnya ${ }^{4}$. Jarak hari pertama menstruasi hingga datangnya menstruasi pada periode berikutnya disebut siklus menstruasi. Siklus menstruasi nomal berada dalam kisaran 21 - 35 hari dan siklus menstruasi rata-rata terjadi selama 28 hari $^{5}$. Macam-macam gangguan siklus menstruasi yaitu polimenore, oligomenore dan amenore $^{6}$. Sebesar $60,2 \%$ dari 108 remaja mengalami siklus menstruasi yang tidak teratur ${ }^{7}$. Terdapat beberapa faktor yang dapat menyebabkan siklus menstruasi yang tidak normal diantaranya yaitu stres, konsumsi gizi, merokok, konsumsi obat hormonal dan gangguan endokrin dan status gizi ${ }^{8}$. Karakteristik remaja yang memperhatikan body image utamanya pada remaja perempuan yang ingin memiliki tubuh langsing menyebabkan remaja melakukan pengaturan pola makan yang terlalu ketat demi menjaga penampilannya. Body image tersebut akan berdampak pada kurangnya asupan yang dikonsumsi sehingga berdampak pada status gizi kurang ${ }^{1}$. Disisi lain, gaya hidup remaja yang cenderung sedentary atau cenderung melakukan aktivitas fisik yang rendah dan konsumsi makanan yang berlebih akan dapat meningkatkan resiko terjadinya kegemukan hingga obesitas. Resiko gizi lebih 3 kali lebih besar pada seseorang dengan aktivitas fisik yang ringan dibandingkan dengan aktivitas fisik sedang dan berat ${ }^{9}$. Aktivitas fisik yang rendah berhubungan dengan kejadian gizi lebih pada remaja. Hubungan aktivitas fisik dengan kejadian gizi lebih berkaitan dengan ketidakseimbangan pengeluaran energi yang masuk dan keluar. Sisa energi yang tidak digunakan dalam tubuh akibat rendahnya aktivitas fisik akan berubah menjadi lemak tubuh yang berhubungan dengan gizi lebih ${ }^{10}$. Seseorang dengan status gizi lebih hingga obesitas beresiko 1,89 kali lebih besar mengalami siklus menstruasi yang tidak teratur dibandingkan seseorang dengan status gizi normal11. Gangguan siklus menstruasi juga terjadi pada seseorang dengan status gizi kurang. Status gizi dapat memberikan gambaran simpanan lemak tubuh seseorang. Lemak tubuh yang kurang atau berlebihakan berpengaruh terhadap produksi hormon esterogen yang berdampak pada siklus menstruasi ${ }^{12}$. Dampak kesehatan dari gangguan siklus menstruasi yang pendek jika tidak tangani dengan baik dapat menyebabkan pengeluaran darah yang lebih sering sehingga kemungkinan dapat menyebabkan anemia pada remaja. Selain itu, siklus menstruasi yang tidak normal dapat menandakan tidak adanya ovulasi (anovulasi) pada siklus menstruasi. Hal tersebut menunjukkan bahwa seseorang dalam keadaan infertilitas yang berarti seseorang tersebut susah untuk memiliki keturunan ${ }^{4}$. Selain itu, panjang siklus menstruasi digunakan sebagai prediktor kesehatan seperti terjadinya kanker payudara dan faktor risiko untuk penyakit kardiovaskular. Jika hal tersebut terus dibiarkan, maka akan berdampak pada kondisi kesehatan wanita masa yang akan datang sehingga perlu adanya penanganan lebih lanjut terkait gangguan siklus menstruasi. Berdasarkan hasil RISKESDAS 2010, prevalensi nasional gangguan siklus menstruasi adalah sebesar $13,7 \%$ dan prevalensi Jawa Timur yaitu sebesar $13,3 \%$. Hal ini menandakan bahwa jumlah kejadian gangguan siklus menstruasi di Jawa Timur hampir sepadan dengan prevalensi Nasional. Lamongan merupakan salah satu kabupaten yang ada di Jawa Timur. Berdasarkan hasil studi pendahuluan di MAN 1 Lamongan di dapatkan hasil sebesar $42 \%$ siswi mengalami siklus menstruasi yang tidak normal. Berdasarkan paparan diatas maka perlu dilakukan analisis terkait hubungan antara status gizi dengan siklus menstruasi pada siswi MAN 1 Lamongan.

\section{METODE}

Analitik observasional merupakan jenis dari penelitian ini dan cross sectional merupakan desain dari penelitian ini. Penelitian dilakukan di MAN 1 Lamongan pada bulan juli 2019. MAN 1 Lamongan di pilih sebagai lokasi penelitian karena berdasarkan hasil studi pendahuluan menunjukkan prevalensi remaja yang mengalami siklus menstruasi yang tidak normal yaitu sebesar $42 \%$. Berdasarkan hal tersebut diketahui bahwa prevalensi siklus menstruasi yang tidak normal lebih tinggi dari prevalensi Nasional yaitu sebesar $13,7 \%$. Populasi pada penelitian ini yaitu siswi kelas $X$ dan $\mathrm{XI}$ MAN 1 Lamongan yang berjumlah 557 siswi. Sampel didapatkan dari perhitungan rumus Lemeshow dan didapatkan hasil sebanyak 83 siswi $^{13}$. Simple random sampling merupakan teknik dalam pengambilan sampel penelitian. Kriteria inklusi pada penelitian ini yaitu siswa yang tidak mengalami cacat bawaan dan dalam keadaan sehat. Kriteria eksklusi pada penelitian ini adalah siswa yang mempunyai penyakit serius sehingga tidak dapat diukur tinggi dan berat badan. Variabel independen pada penelitian ini adalah status gizi dan variabel dependen pada penelitian ini adalah siklus menstruasi. Teknik pengambilan data pada penelitian ini yaitu dengan melakukan pengukuran tinggi badan dengan menggunakan mikrotoise, pengukuran berat badan 
dengan menggunakan digital scale untuk mendapatkan data status gizi dan wawancara menggunakan kuisioner untuk mendapatkan data terkait identitas, usia, usia menarche, jumlah uang saku untuk makan, dan siklus menstruasi responden selama 2 bulan terakhir. Siklus menstruasi dikategorikan menjadi normal jika siklus menstruasi berlangsung pada 21-35 hari dan tidak normal jika siklus menstruasi $<21$ hari dan $>35$ hari ${ }^{6}$. Data berat badan, tinggi badan dan usia yang telah didapatkan digunakan untuk mengetahui status gizi responden melalui software WHO Anthro Plus sehingga didapatkan nilai Z-score IMT/U. Status gizi diklasifikasikan sesuai dengan kategori Z-score IMT/U untuk anak umur 5-18 tahun dari Kemenkes RI tahun 2011. Status gizi dikatakan sangat kurus jika nilai Zscore $<-3$ SD, kurus jika nilai Z-score -3 SD hingga 2 SD, normal jika Z-score $>2$ SD, gemuk jika nilai Z-score $>1$ SD hingga $2 \mathrm{SD}$, dan obesitas jika nilai Z-score $>2 \mathrm{SD}^{14}$. Uji hubungan antara status gizi dengan siklus menstruasi dilakukan dengan uji korelasi Spearman dengan $\alpha=0,05$. Uji korelasi Spearman dapat digunakan untuk data kategorikal dengan minimal skala data ordinal15. Uji korelasi Spearman dilakukan pada penelitian ini karena pada penelitian ini menggunakan skala data ordinal pada kedua variabel.

\section{HASIL DAN DISKUSI}

Usia responden pada penelitian ini berkisar antara 14-17 tahun. Tabel 1 menunjukkan bahwa sebesar 59\% responden berusia 15 tahun dengan ratarata usia 15,33 tahun. Menarche merupakan menstruasi pertama yang dialami oleh remaja perempuan pada masa pubertas. Berdasakan hasil penelitian menunjukkan rata-rata usia menarche siswi MAN 1 Lamongan adalah pada usia 12 tahun. Sebanyak $43,4 \%$ responden mengalami menarche pada usia 12 tahun. Usia menarche telah mengalami pergeseran menjadi lebih dini diberbagai negara. Salah satu faktor yang mempengaruhi usia menarche adalah status gizi ${ }^{16}$. Status gizi erat kaitannya dengan simpanan lemak dalam tubuh $^{17}$. Usia menarche akan semakin dini jika persen lemak tubuh remaja tersebut tinggi ${ }^{16}$.

Uang saku dapat mempengaruhi pemilihan makan remaja. Tabel 1 menunjukkan distribusi uang saku siswi MAN 1 Lamongan. Rata-rata uang saku siswi MAN 1 Lamongan adalah sebesar Rp.13.619 setiap harinya. Sebanyak $56,5 \%$ responden memiliki uang saku kurang dari rata-rata. Besar uang saku dapat mempengaruhi pola konsumsi remaja. Remaja dengan besar uang saku yang tergolong tinggi cenderung lebih sering mengonsumsi makanan jajanan dibandingkan remaja dengan uang saku yang kecilli ${ }^{18}$. Jumlah uang saku berhubungan dengan kebiasaan remaja dalam mengonsumsi makanan ketika di luar rumah ${ }^{19}$.Kebiasaan makan diluar rumah atau makanan jajanan tersebut dapat berhubungan dengan status gizi remaja ${ }^{20}$.

Status gizi siswi MAN 1 Lamongan dapat diketahui pada tabel 2 yang menunjukkan bahwa lebih dari setengah jumlah responden termasuk dalam kategori status gizi normal (66,3\%). Namun masih terdapat responden dengan kategori sangat kurus $(2,4 \%)$, kurus $(4,8 \%)$, gemuk $(18,1 \%)$ dan obesitas $(8,4 \%)$.
Tabel 1. Karakteristik Responden

\begin{tabular}{lcc}
\hline Karakteristik Responden & $\begin{array}{c}\text { Jumlah } \\
(\mathrm{n})\end{array}$ & $\begin{array}{c}\text { Persentase } \\
(\%)\end{array}$ \\
\hline Usia & 4 & 4,8 \\
14 tahun & 49 & 59,0 \\
15 tahun & 29 & 34,9 \\
16 tahun & 1 & 1,2 \\
17 tahun & & \\
& & \\
Usia Menarche & 4 & 4,8 \\
9 tahun & 2 & 2,4 \\
10 tahun & 8 & 9,6 \\
11 tahun & 36 & 43,4 \\
12 tahun & 25 & 30,1 \\
13 tahun & 7 & 8,4 \\
14 tahun & 1 & 1,2 \\
15 tahun & & \\
& & \\
Uang Saku untuk Makan & & 56,6 \\
$\quad$ Rata-rata (Rp.13.619) & 47 & 43,7 \\
$\quad$ Rata-rata(Rp.13.619) & 36 & \\
\hline
\end{tabular}

Status gizi yang tidak normal diakibatkan oleh ketidakseimbangan antara asupan zat gizi yang dikonsumsi dengan kebutuhan individu. Status gizi yang tidak normal dapat mempengaruhi siklus menstruasi seseorang. Status gizi dapat menggambarkan persen lemak tubuh seseorang. Persen lemak tubuh tersebut berpengaruh terhadap produksi hormon esterogen. Hormon esterogen tersebut merupakan hormon yang mengatur siklus menstruasi sehingga dapat mempengaruhi siklus menstruasi seseorang ${ }^{12}$.

Tabel 2. Status Gizi Responden

\begin{tabular}{lrc}
\hline \multicolumn{1}{c}{$\begin{array}{c}\text { Kategori Status Gizi } \\
\text { IMT/U }\end{array}$} & Jumlah (n) & $\begin{array}{c}\text { Persentase } \\
(\%)\end{array}$ \\
\hline Sangat Kurus (<-3 SD) & 2 & 2,4 \\
Kurus (-3SD s/d <-2 SD) & 4 & 4,8 \\
Normal (-2 SD s/d 1 SD) & 55 & 66,3 \\
Gemuk (>1 SD s/d 2 SD) & 15 & 18,1 \\
Obesitas (> 2 SD) & 7 & 8,4 \\
Total & 83 & 100 \\
\hline
\end{tabular}

Siklus menstruasi merupakan jarak waktu dari hari pertama menstruasi sampai datangnya menstruasi pada periode berikutnya ${ }^{5}$. Tabel 3 menunjukkan siklus menstruasi siswi MAN 1 Lamongan. Sebagian besar siklus menstruasi siswi MAN 1 Lamongan termasuk dalam kategori siklus yang normal (62,7\%). Namun, masih terdapat responden yang mengalami siklus menstruasi yang tidak normal yaitu sebesar $37,3 \%$. Tidak teraturnya siklus menstruasi dapat menandakan terjadinya anovulasi pada siklus menstruasi ${ }^{4}$

Tabel 3. Siklus Menstruasi Responden

\begin{tabular}{llc}
\hline $\begin{array}{c}\text { Kategori Status Gizi } \\
\text { IMT/U }\end{array}$ & Jumlah $(\mathrm{n})$ & $\begin{array}{c}\text { Persentase } \\
(\%)\end{array}$ \\
\hline Normal (21-35 hari) & 52 & 62,7 \\
Tidak Normal & 31 & 37,3 \\
Total & 83 & 100 \\
\hline
\end{tabular}




\section{Hubungan Antar Variabel}

Berdasarkan tabel 4 dapat diketahui bahwa nilai $\mathrm{p}$ pada uji korelasi antara kedua variabel yaitu status gizi dengan siklus menstruasi menunjukkan $p=$ 0,036 yang artinya nilai $p<0,05$. Berdasarkan hasil tersebut menandakan bahwa status gizi dengan siklus menstruasi berhubungan. Siswi dengan status gizi obesitas, lebih banyak mengalami siklus menstruasi yang tidak normal dibandingkan siswi dengan status gizi normal. Sebagian besar responden dengan status gizi normal memiliki siklus menstruasi yang normal $(69,1 \%)$. Sedangkan responden yang memiliki status gizi obesitas sebagian besar memiliki siklus menstruasi yang tidak normal $(71,4 \%)$. Hasil penelitian ini sejalan dengan hasil penelitian Nunung yang menunjukkan bahwa ada hubungan antara status gizi dengan siklus menstruasi ${ }^{21}$. Pada penelitian tersebut, seseorang dengan status gizi normal cenderung mengalami siklus menstruasi yang normal dan responden dengan status gizi obesitas cenderung mengalami siklus menstruasi yang tidak normal. Selain itu, hasil penelitian dari Puspitaningtyas juga mendukung hasil penelitian ini. Menurut hasil penelitian Puspitaningtyas menyatakan bahwa status gizi berhubungan dengan siklus menstruasi pada remaja22. Pada hasil penelitian tersebut, responden yang memiliki status gizi normal cenderung mengalami siklus menstruasi yang normal. Status gizi berpengaruh terhadap pertumbuhan, fungsi organ tubuh tidak terkecuali untuk organ reproduksi. Asupan gizi yang sesuai kebutuhan dapat meningkatkan fungsi reproduksi dan berpengaruh terhadap siklus menstruasi. Asupan gizi yang baik, akan mempengaruhi status gizi menjadi baik sehingga hal tersebut dapat membuat kerja hipotalamus menjadi baik untuk memproduksi hormon-hormon reproduksi yang dibutuhkan sehingga siklus menstruasi bisa menjadi teratur ${ }^{23}$.

Tabel 4. Hasil Hubungan Status Gizi dengan Siklus Menstruasi

\begin{tabular}{|c|c|c|c|c|c|c|c|}
\hline \multirow{3}{*}{ Status Gizi } & \multicolumn{4}{|c|}{ Siklus Menstruasi } & \multirow{2}{*}{\multicolumn{2}{|c|}{ Total }} & \multirow{3}{*}{$p$-value } \\
\hline & \multicolumn{2}{|c|}{ Normal } & \multicolumn{2}{|c|}{ Tidak Normal } & & & \\
\hline & $\mathrm{n}$ & $\%$ & $\mathrm{n}$ & $\%$ & $\mathrm{n}$ & $\%$ & \\
\hline Sangat Kurus & 1 & 50 & 1 & 50 & 2 & 100 & \multirow{5}{*}{0,036} \\
\hline Kurus & 4 & 80 & 1 & 20 & 5 & 100 & \\
\hline Normal & 38 & 69,1 & 17 & 30,9 & 55 & 100 & \\
\hline Gemuk & 7 & 50 & 7 & 50 & 14 & 100 & \\
\hline Obesitas & 2 & 28,6 & 5 & 71,4 & 7 & 100 & \\
\hline
\end{tabular}

Status gizi pada perempuan ketika dalam kondisi kelebihan maupun kekurangan dapat menyebabkan fungsi hipotalamus menurun sehingga tidak memberikan stimulasi kepada hipofisis anterior untuk mengekskresi FSH (Folicle Stimulating Hormone) dan LH (Leuteinizing Hormone) ${ }^{24}$. Pada remaja yang mengalami gizi lebih terjadi peningkatan jumlah hormon esterogen dalam darah dikarenakan meningkatnya jumlah lemak tubuh. Kadar hormon esterogen yang tinggi memberikan feedback negatif terhadap produksi GnRH (Gonadotropin Hormone) melalui sekresi protein inhibitor yang dapat menghambat kerja hipofisis anterior untuk memproduksi hormon FSH. Hambatan tersebut menyebabkan gangguan proliferasi folikel sehingga folikel tidak dapat terbentuk secara matang yang berakibat pada terjadinya pemanjangan siklus menstruasi. Peningkatan hormon esterogen juga memberikan feedback positif pada hormon LH sehingga terjadi peningkatan kadar hormon LH secara cepat dalam tubuh. Kerja hormon $\mathrm{LH}$ beriringan dengan hormon FSH. Jika terjadi gangguan pada sekresi FSH maka LH juga tidak berjalan dengan baik. LH yang terlalu cepat keluar menyebabkan pertumbuhan folikel baru terus menerus distimulasi namun tidak sampai pada proses pematangan dan ovulasi sehingga menyebabkan siklus menstruasi yang tidak normal ${ }^{25}$. Status gizi kurang dapat menyebabkan gangguan fungsi reproduksi. Penurunan berat badan dapat menyebabkan penurunan produksi GnRH untuk pengeluaran hormon LH dan FSH yang mengakibatkan kadar hormon esterogen mengalami penurunan sehingga berdampak negatif pada siklus menstruasi yaitu menghambat terjadinya proses ovulasi. Hal ini dapat menyebabkan terjadinya pemanjangan siklus menstruasi ${ }^{26}$.

Namun, pada hasil penelitian ini responden dengan status gizi kurang cenderung mengalami siklus menstruasi yang normal dan setengah dari responden dengan status gizi gemuk mengalami siklus menstruasi yang normal. Hal ini kemungkinan disebabkan oleh faktor lainselain status gizi karena siklus menstruasi wanita sangat mudah dipengaruhi oleh keadaankeadaan lain sehingga masih terdapat responden dengan status gizi kurang maupun gemuk namun memiliki siklus menstruasi yang normal. Faktor-faktor lain yang kemungkinan dapat mempengaruhi siklus menstruasi diantaranya yaitu stres, asupan zat gizi, serta banyak faktor lainnya yang kemungkinan berpengaruh terhadap produksi hormon reproduksi. Seseorang yang mengalami stres cenderung mengalami siklus menstruasi yang tidak normal dan sebaliknya, seseorang yang tidak mengalami stres akan memiliki siklus menstruasi yang normal ${ }^{5}$. Selain itu, asupan zat gizi juga dapat mempengaruhi siklus menstruasi. Asupan gizi yang baik dapat meningkatkan fungsi reproduksi dan berpengaruh terhadap siklus menstruasi ${ }^{23}$. Remaja dengan asupan gizi yang baik, memiliki menejemen stres yang baik serta gaya hidup dan pola makan yang baik dapat membuat kerja hipotalamus menjadi baik sehingga dapat memproduksi hormon-hormon yang dibutuhkan oleh tubuh, tidak terkecuali dengan hormon reproduksi yang berkaitan dengan siklus menstruasi ${ }^{27}$. 


\section{KESIMPULAN}

Terdapat hubungan antara status gizi dengan siklus menstruasi pada siswi MAN 1 Lamongan. Siswi dengan status normal cenderung memiliki siklus menstruasi yang normal dan siswi dengan status gizi obesitas cenderung memiliki siklus menstruasi yang tidak normal. Sebagian besar status gizi remaja mempunyai status gizi normal dengan siklus menstruasi yang normal. Status gizi merupakan salah satu penyebab terjadinya gangguan siklus menstruasi sehingga perlu adanya pendidikan gizi terkait gizi pada remaja. Gizi seimbang perlu diterapkan oleh siswi supaya dapat pengaturan pola makan baik dari jumlah dan kualitas makanan serta melakukan aktivitas fisik yang cukup agar tercipta status gizi yang normal. Jika hal tersebut dilakukan maka kemungkinan akan memperkecil risiko untuk mengalami gangguan siklus menstruasi.

\section{ACKNOWLEDGEMENT}

Ucapan terima kasih kami ucapkan kepada Kepala Madrasah Aliyah Negeri 1 Lamongan yang telah memberikan ijin penelitian di MAN 1 Lamongan, serta kepada seluruh guru dan staf, siswi yang telah bersedia menjadi responden,

\section{REFERENSI}

1. Adriani, M. \& Wirjatmadi, B. Peranan Gizi dalam Siklus Kehidupan. (Kencana Prenada Media Group, 2016).

2. Sinaga, E., Saribanon N, Suprihatin, Sa'adah N, Salamah U., et al. Manajemen Kesehatan Menstruasi. (Universitas Nasional, 2017).

3. Irianto, K. Kesehatan Reproduksi Teori dan Praktikum. (Alfabeta, 2015).

4. Novita, R. Hubungan Status Gizi dengan Gangguan Menstruasi pada emaja di SMA AlAzhar Surabaya. Amerta Nutr.2, 172-181 (2018).

5. Tombokan, K.C., Pangemanan, D.H.C., Engka, J. N. . Hubungan antara Stres dan Pola Siklus Menstruasi pada Mahasiswa Kepaniteraan Klinik Madya (Co-Assistant) di RSUP Prof. Dr. R. D. Kandau Manado. J. e-Biomedik5, (2017).

6. Wiknjosastro, H. Ilmu Kandungan. (Yayasan Bina Pustaka Sarwono Prawiroharjo, 2009).

7. Hidayah, N,. Rafiludin, M.Z., Aruben, R. Hubungan Status Gizi, Asupan Zat Gizi, dan Aktivitas Fisik dengan Siklus Menstruasi Remaja Putri Pondok Pesantren Salafiyah Kauman Kabupaten Pemalang Tahun 2016. J. Kesehat. Masy.4, (2016).

8. Kusmiran, E. Kesehatan Remaja dan Wanita. (Salemba Medika, 2014).

9. Putra, W. Hubungan Pola Makan, Aktivitas Fisik dan Aktivitas Sedentary dengan Overweight di SMA Negeri 5 Surabaya. J. Berk. Epidemiol.5, 298-310 (2017).

10. Atkinson, R. Etiologies of Obesity. Di dalam: The Management of Eating Disorder and Obesity.
(Humana Press. Inc, 2005).

11. Rachmawati, A., \& Dieny, F. Hubungan Obesitas dengan Gangguan Siklus Menstruasi pada Wanita Dewasa Muda. J. Nutr. Collage2, 214222 (2013).

12. Caroline, M. Pengantar Pangan dan Gizi. (PT Penebar Swadaya, 2010).

13. Lemeshow, S., Hosmer, D.W., Klar, J. and Lwangsa, S. Adequacy of Sample Size in Health Study. (John Willet \& Sons Ltd., 1990).

14. Kementerian Kesehatan RI. Keputusan Menteri Kesehatan Republik Indonesia. (Direktorat Bina Gizi, 2011).

15. Riadi, E. Statistika Penelitian. (AndiPublisher, 2016).

16. Makarimah, A., Muniroh, L. Hubungan antara Status Gizi, Persen Lemak Tubuh, Pola Konsumsi, dan Aktivitas Fisik dengan Usia Menarche Anak Sekolah Dasar. Media Gizi Indones.12, 191-198 (2017).

17. Acharya, A., Reddaiah, V.P., dan Baridalyne, N. Nutritional Status in Adolescent Girls in an Urban Resettlement Colony of South Delhi. Indian J. Community Med.31, 302-303 (2006).

18. Aulia, I. Hubungan Antara Karakteristik Siswa, Pengetahuan, Media Massa dan Teman Sebaya dengan Konsumsi Makanan Jajanan pada Siswa SMA Negeri 68 Jakarta. (Universitas Indonesia, 2012).

19. Lachat, C., Nago, H.E.S., Verstraeten, R., Roberfroid, D., Camp., J.V., Kolsteren, P. Eating Out of Home in Vietnamese Adolescent Sosioeconomic Factors and Dietary Association. J. Clin. Nutr.90, 1648-1655 (2009).

20. Nuryani dan Rahmawati. Kebiasaan Jajan Berhubungan dengan Status Gizi Siswa Anak Sekolah di Kabupaten Gorontalo. Indones. J. Nutr.6, 2338-3119 (2018).

21. Nunung. Hubungan Antara Status Gizi dengan Siklus Menstruasi pada Remaja Putri di SMAN 1 Bantul Yogyakarta. (Sekolah Tinggi Ilmu Kesehatan Jenderal Achmad Yani Yogyakarta, 2017).

22. Puspitaningtyas, D. I. Hubungan Antara Status Gizi dengan Siklus Menstruasi Pada Remaja Putri di SMA Negeri 2 Surakarta. (Universitas Sebelas Maret, 2014).

23. Felicia, F., Hutagaol, E., Kundre, R. Hubungan Status Gizi dengan Siklus Menstruasi pada Remaja Putri di PSIK FK UNSRAT Manado. ejournal Keperawatan (eKp)3, (2015).

24. Marmi. Gizi dalam Kesehatan Reproduksi. (Pustaka Belajar, 2013).

25. Baziad, A. Kontrasepsi Hormonal. (PT Bina Pustaka Sarwono Prawirohardjo, 2008).

26. Paath, E. Gizi dalam Kesehatan Reproduksi. (EGC, 2005).

27. Mentari. Hubungan Status Gizi dengan Gangguan Menstruasi pada Remaja Putri di Akademi Kebidanan Cipto Medan. (Universitas Sumatera Utara, 2015). 